Prof. dr. Refik Ćatić

\title{
Osobenosti problemskog učenja
}

Sažetak

Savremene pedagoške koncepcije se temelje na nastavi usmjerenoj na učenika. Za razliku od tradicionalne nastave, u novim odgojno-obrazovnim sistemima nastavnik je sve više posrednik između obrazovnih sadržaja $i$ učenika. On potiče učenike da istražuju $i$ otkrivaju i tako stiču znanja iz prve ruke. "Onaj tko nas želi poučiti istini ne bi nam trebao reći ,već jednostavnim gestom,gestom koja započinje idealnu putanju zrakom, po kojoj klizimo sve dok se ne nađemo pod nogama nove isitine" (H.Džubran,Prorok).Problemska nastava je koncept koji je oslonjen na potrebu djeteta da istražuje svijet koji ga okružuje, zbog čega ovaj rad sublimira osnovne teorijske postavke takvih odgojno-obrazovnih strategija .

\section{Uvod}

Jedan od značajnih ciljeva današnje škole je osposobljavanje učenika za cjeloživotno obrazovanje. Sve se više insistira na istraživačkom radu učenika, te na razvijanju njihove samostalnosti. Zahtjev našeg vremena je efikasno učenje, a suština povećanja efikasnosti leži, prije svega, u temeljnoj izmjeni i poboljšanju unutrašnje organizacije rada u školi.

Efikasnost se ne može postići tradicionalnim, a još manje prevaziđenim oblicima i metodama, tako da na prvo mjesto izbijaju aktivne metode učenja.

Jedan od načina povećanja efikasnosti nastave je i učenje putem rješavanja problema. Učenike treba osloboditi unutrašnjih i vanjskih barijera za slobodno mišljenje i postupanje. Treba podsticati originalnost, spontanost, otvorenost, samoinicijativnost, dosjetljivost, korektnost, kritičnost, samokritičnost, fluentnost i fleksibilnost. Škola i klasična nastava to veoma malo ili nimalo ne čine.

Međutim, ako je glavni cilj današnjice naučiti učenike kako se samostalno uči i kako se postavljaju i rješavaju problemi, za 
ostvarenje tog cilja potrebno je jačanje problemske nastave. Potrebno je osavremenjivanje, unošenje novina i traženje novih puteva i načina u učenju kako bi znanje bilo kvalitetnije, trajnije i primjenjivije.

Nastava se može učiniti interesantnom i otkrivačkom ako učenici sami: pronalaze, otkrivaju, izvode zaključke i provjeravaju dobivene rezultate. Oni postaju aktivni sudionici nastavnog procesa. Nastavnik je tu da podstakne, pomogne, usmjeri ka generalizaciji.

\section{Pojam problemskog učenja}

Problemsko učenje je složen misaoni napor kojim se dolazi do novih podataka. Karakteriše ga visoki stepen sposobnosti uočavanja odnosa i uzročno - posljedičnih veza.

Rješavajući probleme osoba samostalnim naporom stječe znanja. Prilikom rješavanja problema potrebno je sagledati što je zadato, a što dano. Dakle, nešto treba riješiti ( zadano), a za to rješavanje već postoje izvjesni podaci ( to je dano).

$\mathrm{Na}$ početku treba istaći da ovo učenje ima brojne druge nazive i sinonime. U našoj i stranoj literaturi susrećemo se sa sljedećim terminima: učenje putem rješavanja problema $u$ nastavi, problematizirana nastava, problemske nastavne situacije, nastava putem problema, problem - situacija, problem - metoda, problemsko izlaganje, zadatak - problem, problemsko učenje itd.

$\mathrm{Na}$ zapadu se ova nastava označava sintagmom problem solving, l'enseignement probleme, entdeckendes Lernen, a u ruskoj literaturi problem je obučenje.

Hašim Muminović u djelu „Mogućnosti efikasnijeg učenja u nastavi“" navodi: "Mi pod problemskim učenjem u nastavi ne mislimo na rješavanje problema uopće, već na one vidove učenja i poučavanja u kojima centralno mjesto zauzima rješavanje problema kao moguća varijanta organizacije i realizacije nastave".

R. Ničković u djelu „Didaktika “ u poglavlju „Vrste učenja "kazuje o suštini učenja putem rješavanja problema i navodi da je to najviši oblik učenja $i$ da je usko povezan s mišljenjem, da je

\footnotetext{
${ }^{1}$ Hašim Muminović, Mogućnosti efikasnijeg učenja u nastavi,Sarajevo, 2001. god.
} 
najintenzivniji oblik nastave, da je svjesna i stvaralačka djelatnost, da ujedinjuje didaktičke, psihološke i gnoseološke aspekte nastave. To je jedan višefazni proces u kome dolaze do izražaja sve pozitivne i negativne strane nastavnog djelovanja. ${ }^{\text {‘2 }}$

Robert Ganje problemsku nastavu definiše kao „tip nastave u kome učenici samostalnim istraživanjem i rješavanjem problema razvijaju stvaralačko mišljenje .“

Vladimir Poljak u djelu „, Didaktika“ ističe: „Ako učenici sami rješavaju problem uz stanovitu pomoć nastavnika, to je problemska nastava."

Učenje putem otkrića sastoji se u tome da sadržaji koje treba naučiti nisu prezentirani učeniku u gotovom obliku već ga oni moraju samostalno otkriti, pa tek onda inkorporirati u svoj kognitivni stil.

Osnovne karakteristike ovog učenja su:

- da učenika čine stalno aktivnim subjektom nastave,

- on razvija sposobnost otkrivanja principa,

- postaje samostalniji i manje zavisan od nastavnika,

- postaje svjesniji svojih intelektualnih mogućnosti,

- omogućava bolji transfer na nove situacije,

- bolje reorganizuje i kombinuje postojeće podatke,

- razvija se jača motivacija za učenje i nastavni rad.

Rješavanje problema može da se odvija putem pokušaja i pogrešaka, ali i na kreativan način.

Učenje putem pokušaja i pogrešaka je ustvari otkrivanje i stalno izvođenje „tačne“ reakcije u problemskoj situaciji koja dozvoljava veliki broj različitih odgovora.

Ovo učenje ima tri karakteristike:

1. Odgovor koji treba učenik naučiti nije precizno određen datim sklopom draži . Učenik mora odabrati tačan odgovor iz većeg broja mogućih reakcija na datu problemsku situaciju.

2 Radislav Ničković, Učenje putem rješavanja problema u nastavi, Zavod za izdavanje udžbenika, Beograd, 1969. god. 
2. Obično se tačan odgovor nalazi u dobro izvježbanom repertoaru učenika, koji posjeduje prije nego što se nađe $u$ novoj situaciji učenja.

3. Šta će biti ,tačan“ odgovor zavisi od specifičnog zadatog problema i tačnost odgovora može se provjeriti samo stvarnim izvođenjem radnje.

Dva osnovna pojma koja se sreću u problemskoj nastavi su problem i problemska situacija.

\section{Problem}

Među stručnjacima nema jedinstvenog mišljenja o tome šta predstavlja problem, tako da se ovaj pojam različito definira. „Problem je riječ grčkog porijekla koja označava određeni zadatak, zagonetku, neriješeno i sporno pitanje. To je situacija u kojoj postoji teškoća, spornost, prepreka, odgovarajuća protivrječnost., koju tvore "dato i zadato."

Problem označava praktičnu ili teorijsku situaciju koja se ne može jednostavno razrešiti; sve ono što vodi spornim gledištima, što izaziva različita i čak protivrečna mišljenja.“

Problem (grč.) predstavlja“" okolnost koja izaziva nedoumicu ili nepriliku, poteškoću, brigu.“

Problem etimološki ( grč.) označava zadatak, pitanje koje traži odgovor,poteškoću. “"

Isti autor navodi da problem sadrži nešto novo, nedoživljeno, nešto što ne postoji u iskustvu. ,,

Mladen Vilotijević u djelu „Didaktika“u poglavlju „Problemska nastava“ ističe: „, Problem se javlja kada učenik naiđe na izvesnu prepreku u zadovoljavanju svojih želja ili povezivanju svojih ciljeva, onda kada naiđe na određenu teškoću, a cilj ne može postići na osnovu do tada važećih načina već valja pronaći put, način za njeno prevazilaženje.“3

\footnotetext{
${ }^{3}$ Mladen Vilotijević, Didaktika, Naučna knjiga, Učiteljski fakiltet, Beograd, 1999. god.
} 
Isti autor navodi: „Problem je zadatak koji ima sledeće odlike:

a) nešto nepoznato, neku prazninu koju treba otkriti i popuniti na osnovu podataka i odnosa koji nisu izričito dati

b) različit broj mogućnosti za rešavanje (jedne ili više)

c) veliku kompleksnost (za rešenje je potreban veliki broj složenih logičkih operacija)

d) mogućnost za rešenje se ne javlja pomoću nekog ustaljenog obrasca, nego je za rešenje potreban stvaralački pristup i iskustvo

e) rešavanjem problema produbljuje se znanje, usvajaju se strukture saznavanja i razvijaju mentalne sposobnosti.“

Vladimir Poljak u jednoj od didaktičkih postavki problemske nastave definira problem kao „subjektivni doživljaj, spoznajni i emocionalni, što znači da subjekt (čovjek) doživljava problem.Što je težina problema veća, to je njegova spoznajna i emocionalna obojenost veća. “4

Mladen Vilotijević takođe navodi: „Pojam problem treba razgraničiti od pojma zadatak. Zadatak je mnogo širi i obuhvatniji pojam. U široki raspon koji ima pojam zadatak smešta se i pojam problem, koji jeste zadatak, ali s mnogo posebnosti koje treba odrediti.“

„Tamo gdje se može doći do cilja lako, nema problema“ ističe B. Stevanović.

Zadaci u problemu se moraju zasnivati na onim znanjima $\mathrm{i}$ iskustvima kojima učenik već raspolaže.

Problem zadaci mogu biti:

- nastavni zadaci, kakvi se zadaju u okviru standardnog školskog gradiva,

- problem pitanja,

- praktični zadaci ( radovi )

\footnotetext{
${ }^{4}$ Vladimir Poljak, Didaktika, Školska knjiga, Beograd, 1974. god.
} 
Potrebno je u nastavnom radu kombinirati sve tri varijante zadovoljavanja zadataka.

\section{Tipologija problema}

Autori navode različite tipoloije problema. To su sljedeći:

\section{S obzirom na odnos početne (problemske) situacije i situacije cilja, Van de Ger probleme dijeli na:}

Problemi interpolacije - ovdje su poznate činjenice početne situacije i situacije cilja. Traženjem veza između ova dva polja rješava se problem.

Problemi ekstrapolacije se manifestiraju u tri oblika:

- poznate su činjenice početne situacije(uvjeti zadatka)

- poznat cilj

- nepoznata i početna situacija i situacija cilja.

1. Milan Bakovljev u djelu „Didakika“ navodi: „Teškoća koja problem čini problemom jeste ili fizičke ili mentalne prirode. Problemi se, dakle, dijele na one koji se tiču konkretnih objekata i na probleme koji su neposredno u vezi isključivo s idejama...

2. Dr. Ničković na sljedeći način dijeli probleme:

a) probleme stjecanja novih znanja

b) problemi primjene stečenih znanja

c) provjerilački problemi.

Problemi se dalje dijele prema različitim kriterijumima:

3.Prema stupnju sudjelovanja misaonih i praktičnih djelatnosti dijele se na:
a) misaone probleme
b) praktične probleme
4. Prema načinu rješavanja:

\footnotetext{
${ }^{5}$ Milan Bakovljev, Didaktika, V izdanje, Naučna knjiga, Beograd, 1998. god. 
a) problemi prikupljanja informacija,

b) problemi s prisjećanjem rješenja, i

c) problemi s objašnjavanjem situacije.

5. Postoje i druge podjele, kao npr.

a) problemi praktičnog karaktera

b) intelektualni ( teorijski ) problemi

c) umjetnički problemi

d) dvosmjerni problemi

e) problemi trajanja

f) verbalni problemi

\section{Problemska situacija}

Sa stanovišta didaktike i psihologije razlike između problema i problemske situacije postoje, na šta upućuje R. Ničković ističući:" Problemska situacija predstavlja početnu kariku u rešavanju shvaćenog i prihvaćenog problema i kao takva ona je doživljaj neizvesnosti, očekivanja, zbunjenosti, radoznalosti, tenzije."

„Problemska situacija je početno psihičko stanje iznenađenja , upitnosti, velike zainteresrianosti i visoke umne i emocionalne napregnutosti pojedinca koji treba riješiti zadati problem.“

Filip Jelavić o problemskoj situaciji navodi sljedeće: “Općenito kao problemsku situaciju označavamo onu situaciju u kojoj se pojedinac više ne može snalaziti na osnovu onoga što zna, što je ranije naučio na osnovi osobnog iskustva. Problemska situacija postoji za pojedinca tek onda kad je on osvijesti i jasno formulira kao pitanje na koje mora dati ( do tada bar njemu nepoznat) odgovor. ${ }^{\text {"6 }}$

Isti autor dalje navodi: "O problemskoj situaciji se radi tek onda kad se do rješenja može doći samo istraživanjem.“

${ }^{6}$ Filip Jelavić, Didaktika, Naklada Slap, Jastrebarsko, 1998. god. 
Po Muji Slatini problemska situacija je stvorena misaono praktična protivrječnost u kojoj ima više različitih problema. ${ }^{\text {" }}$

Mirko Dejić ističe: „Smisao problemske situacije jeste da motiviše učenike za rješavanje problema. Razlog nastajanja problemske situacije jeste izvjesna protivrječnost koja je sadržana u problemu. Kod učenika se pobuđuje interesovanje i želja da se dođe do ukidanja protivrečnosti.

Za stvaranje problemske situacije prezentiraju se neophodni podaci. Korisno je zahtijevati od učenika da samostalno formulišu određenu problemsku situaciju, da se to ne svodi samo na nastavnika. postupcima:

Stvaranje problemske situacije postiže se raznovrsnim

1. otkrivanjem veza i odnosa među datim podacima;

2. pomoću udžbeničkog teksta - da se na osnovu sadržaja postave problemska pitanja;

3. iznošenjem problema u obliku teza s ciljem da se učenik opredjeli za prihvatanje ili odbijanje;

4. primjenom ankete - na listiće se ispisuju pitanja orijentacinog karaktera na koju učenici odgovaraju u usmenoj ili pisanoj formi.

5. sukob protivrječnih činjenica;

6. poznate su početne činjenice i rezultati, treba naći metode za rješavanje;

7. pomoću grafičko - ilustrativnog materijala dovođenjem u vezu s tekstom;

8. interpretativno čitanje da se pronađu relevantne činjenice na osnovama uzročno - posljedičnih veza i odnosa;

9. otkrivanjem veza i odnosa pomoću nastavnih sredstava (zemljopisnih karti itd.)npr.;

10. postavljanje pitanja u vidu problema.

${ }^{7}$ Mujo Slatina, Nastavni metod - prilog pedagoškoj moći suđenja, Filozofski fakultet Univerziteta u Sarajevu, 1998. god.

${ }^{8}$ Mirko Dejić, Metodika nastave matematike, I dio, Jagodina, 2000. god. 


\section{Osnovne karakteristike problemskog učenja}

Problemsko učenje je oblik efikasnog učenja koji se odlikuje:

- postojanjem teškoće, novinom situacije i protvirječjem između poznatog i nepoznatog,

- svjesnom, usmjerenom, stvaralačkom i što samostalnijom aktivnošću pomoću koje učenik teži da, uviđanjem odnosa između datog i zadatog i nalaženja novih puteva rješenja, usvoji nova znanja i stvori nove generalizacije, primjenjive $u$ novim situacijama.

Bit problemskog učenja svodi se na dva osnovna aspekta:

- logika naučnog istraživanja

- zakonitost psihologije mišljenja

Bitnu karakteristiku problemskog učenja čini to što je nastavni sadržaj (zakonitosti prirode, društva i ljudskog mišljenja date $\mathrm{u}$ njemu), aktivnosti koje proizlaze iz njega su u direktnoj vezi sa onim ko uči ili koga poučavamo. Učenik sve problema učenja i poučavanja doživljava na sopstvenoj koži.

Rješavajući probleme $u$ nastavi učenici analiziraju, sintetiziraju, otkrivaju, zaključuju, uviđaju, opažaju, organizuju, verifikuju. Iz te aktivnosti proizilaze karakteristike nastavnog rada koje čini visok nivo saznanja, visoka trajnost znanja, veća utemeljenost navika i iznijansiranost umijeća.

Među pretpostavkama za primjenu problemskog učenja spadaju i pripreme nastavnika. Njegova uloga se mijenja u odnosu na rad $\mathrm{u}$ frontalnoj komunikaciji razredno - časovnog tipa $\mathrm{i}$ on postaje koordinator, rukovodilac, konsultant, voditelj odgojno - obrazovnog zbivanja na ovaj način. Sva pozitivna svojstva nastavnika ovdje treba da dođu do izražaja.

U nastavi ovog tipa otklonjen je formalizam, enciklopedizam, fiksiranost i fobičnost. Nastavni proces je dinamičniji, uređeniji, sistematičniji, logičniji i uozbiljeniji. Učenik je, uz povećanu aktivnost, svjesniji tokova i ishoda nastavnog rada. Karakteriše ga specifična komunikacija sa nastavnicima i drugim akterima nastave. 
U problemskom učenju postoje suprotnosti između:

- danog i zadanog

- eksplicitnog i implicitnog

- poznatog i nepoznatog

- starog i novog.

Problemsko učenje u nastavi ima karakteristike istraživačkog rada. Učenici se u usvajanju činjenica ponašaju poput naučnog istraživača, samostalno istražuju i otkrivaju, a u tom procesu zastupljeni su svi procesi misaone aktivnosti.

Kada se zna da problemska nastava ne isključuje niti jedan organizacioni oblik nastavnog rada (individualni, rad u parovima, grupni i kolektivni oblik rada) niti bilo koji metodičko - izvedbeni vid nastave (predavačko - informativni, individualizirani, programirani, heuristički), onda je sasvim jasno zašto se ovoj nastavi treba dati primat.

Neizostavne pretpostavke u sagledavanju učenja putem rješavanja problema su ličnost učenika i motivacija. Bez određenih osobina ličnosti i njenog motivaciono - emotivnog odnosa prema problemima i problemskim situacijama teško je postići željene rezultate.

Ona treba bitno uticati na otklanjanje slabosti koje stalno reprodukuje klasična nastava, a koje se iskazuju u njegovanju mehaničkog pamćenja umjesto mišljenja, u reprodukciji umjesto produkciji, u kopiranju i oponašanju umjesto stvaralaštva.

Cilj problemske nastave je:

- razumijevanje postavljenog problema

- razvijanje sposobnosti artikulacije misaonog procesa

- razvijanje komunikacijskih sposobnosti.

\section{Didaktičke vrijednosti i značaj problemskog učenja}

Sa pedagoško - psihološkog i didaktiočko - metodičkog aspekta veliki je značaj primjene problemskog učenja. 
Osnovne didaktičke vrijednosti i značaj problemskog učenja su:

- povećava efikasnost odgojno - obrazovnog rada

- ubrzava razvoj mentalnih sposobnosti i psihičkih funkcija

- osigurava aktivno učenje

- podstiče učenike da sami rješavaju zadatke i osamostaljuje ih

- razvija sposobnosti apstraktnog mišljenja kao najviše intelektualne aktivnosti

- osigurava upoznavanje različitih tehnika i metoda efikasnog učenja

- pojačava motivaciju

- povećava kvantitet znanja

- povećava transfer znanja

- povećava odgojno - obrazovni kvalitet nastave

- uspješno razvija misaone operacije (analizu, sintezu, apstrakciju, generalizaciju, indukciju, dedukciju itd.)

- povećava trajnost znanja

- razvija inventivnost, originalnost i osjetljivost za probleme

- dinamizira nastavni proces

- njeguje kritičnost, fleksibilnost, fluentnost i kreativnost

- smanjuje greške u mišljenju

- razvija sposobnosti uviđanja bitnih odnosa i veza

- zahtijeva korištenje različitih izvora za stjecanje znanja

- navikava učenike da naučeno primjenjuju u praksi, da postojeće znanje koriste u novim situacijama, tj. povećava primjenjivost stečenih znanja

- jača učeničko samopouzdanje

- obezbjeđuje mogućnost za redovnu povratnu informaciju, samim tim i kontinuirano praćenje i vrednovanje rada učenika što ih motiviše da bolje i upornije rade

- omogućuje nastavniku da na osnovu povratne informacije koriguje nastavni proces, da otkloni slabosti i tako uspješno ostvari postavljeni cilj i zadatke

- racionalizira psihofizičku energiju, vrijeme, materijalna i tehnička sredstva 


\section{Slabosti i ograničenja problemskog učenja:}

- svi nastavni sadržaji nisu pogodni za problemsko učenje. To je važno, jer u tom slučaju oni sadržaji koji samo jednim dijelom ispunjavaju uvjete za ovaj pristup učenju trebaju biti ozbiljno razmotreni radi složenijih priprema koje predstoje;

- problemsko učenje može destimulirati, odbiti i zastrašiti određene tipove učenika;

- ono nema smisla kod onih učenika koji ne prihvataju probleme i problemske situacije, koji neće da ovladavaju tehnikama i postupcima rješavanja problemskih situacija.

\section{Mogućnost primjene problemskog učenja}

Dva su činioca o kojima treba razmisliti kad se nastavnik odlučuje da primijeni problemsku nastavu - uzrast i nastavni predmet.

Ranije se mislilo da djeca mlađeg školskog uzrasta još nisu biološki stasala da apstraktno misle, što je uslov za rješavanje problema. Pokazalo se, međutim, da nije tako. Lav Vigotski je svojim istraživanjem došao do pouzdanog zaključka da i djeca u tom uzrastu mogu apstraktno misliti.

On se zalagao da se apstraktno mišljenje razvija tako što će se djeci davati zadaci, koji svojim zahtjevima premašuju trenutno dostignuti razvoj, da bi se tako osvojila zona narednog razvoja i ubrzao intelektualni razvoj djece.

Rješavanje problema izrazito je efikasno kada se primjenjuje grupni oblik rada, naročito kod učenika osnovne škole. Problemska nastava se planira u godišnjem planu svakog nastavnika.

Tačno se predviđaju teme i nastavne jedinice koje će biti obrađene problemskom nastavom. Nastavnik će, pri tome imati u vidu da nisu u podjednakoj mjeri sve nastavne jedinice pogodne za obradu putem problemske nastave.

Težina problema treba odgovarati uzrastu učenika i treba se imati u vidu da se manja djeca ne mogu dugo koncentrirati na problem. 
Problemski zadaci su odlično sredstvo za ostvarivanje tog cilja. Jasno je da zadaci treba da budu prilagođeni uzrastu, ali i u okviru te prilagođenosti oni moraju sadržavati problemsku teškoću. U svakom nastavnom predmetu postoje problemi, a to znači da se rješavanje problema kao sredstvo za sticanje znanja i razvoj mišljenja može primijeniti u svakoj oblasti.

Sva područja nastavnog rada, u manjoj ili većoj mjeri, raspolažu sa sadržajima i organizacionim formama za problemsko učenje. Svi sadržaji ne mogu biti predmet problemskog učenja u nastavi , ali se može tačno odrediti koji jesu, a koji nisu.

Njega treba afirmirati na onim sadržajima koji su za to podobni.

Ali nije svaki predmet podjednako pogodan za primjenu problemske nastave. Džerom Brunner je tražio da $\mathrm{u}$ nastavnim programima dominiraju sadržaji koji su logički dosljedno strukturirani i naučno egzaktni naglašavajući da su to matematika i prirodne nauke koje najviše doprinose razvoju mentalnog kapaciteta.

No, i u drugim predmetima je moguće i potrebno postupno rješavati problemske zadatke. Pri tome treba voditi računa o pogodnosti nastavne teme. Ako ona omogućava postavljanje zadataka sa nekom problemskom teškoćom, nepoznanicom, može se problemski obrazovati, ponavljati i utvrđivati.

Rješavanje problema treba uvoditi u nastavu postepeno. Na času obrade novog ili ponavljanja obrađenog gradiva, nastavnik može postaviti neko problemsko pitanje radi uvođenja i navikavanja učenika na takav način rada.

Problemske teškoće treba postepeno povećavati. Kod podsticanja interesa za rješavanje problema, neophodno je, voditi računa o realizaciji, mogućnostima učenika i zahtjevima koji im se postavljaju.

Mogućnosti učenika zavise od većeg broja činilaca: nivoa psihičkog razvoja, obima informacija o pojedinim područjima, stečenim iskustavima, emocionalnoj zrelosti, motivacije koja utiče na aktivan odnos prema problemu i utiče na napor potreban za prisjećanje neophodnih elemenata $\mathrm{i}$ činjenica. 
Rješavanje problema je jedan od vidova nastavnog rada kojim se postiže velika misaona aktivnost učenika. Treba ga koristiti u onim predmetima $\mathrm{i}$ onim tematskim cjelinama $\mathrm{u}$ kojima $\mathrm{za}$ to postoje najbolje mogućnosti.

Motivacija je osnova svakog dobro organiziranog rada, a posebno složenog kakvo je preoblemsko učenje. Učenik treba osjetiti unutrašnju potrebu, nagon, želju da određeni problem, zadatak riješi. Tada se javlja potpunija misaona aktivnost,koja je osnova za uviđanje veza i odnosa među datim podacima, odnosno uvjet za rješavanje problema.

Za motivaciju učenika mogu poslužiti raznovrsni načini i postupci od kojih pravilno definiranje problemske situacije ima posebno značenje.

Nije preporučljivo da se u nekom predmetu praktikuje samo ovaj tip nastave. Nastavnik na početku školske godine treba planirati koje će teme i sadržaje obraditi rješavanjem problema. Pri tome vodi računa o prirodi gradiva.

Obrada sadržaja na problemski način zahtjeva više vremena i truda od obrade na klasičan način, ali su za to rezultati ubjedljivo bolji. Učenici su misaono potpuno aktivni, a samostalno dolaženje do rezultata maksimalno ih motivira na nove napore.

Navest ćemo nekoliko didaktičkih vrijednosti za koje smatramo da su od posebnog značaja. Problemska nastava se može s velikim uspjehom primjenjivati u svim nastavnim oblastima i kod sve dobi djece i učenika, uključujući i predškolski odgoj.

Naročito efikasna primjena zapažena je u nastavi fizike, matematike, biologije i hemije i drugih prirodnih nauka, a nešto manja u društvenim naukama.

Mogućnost primjene problemske nastave zavise, pored ostalih i od sljedećih činilaca:

- dobi učenika,

- stupnja individualnog psihičkog razvoja,

- emocionalnog stanja,

- motivacije,

- opsega informacija kojima učenik raspolaže, 
- osjetljivosti za uviđanje problema,

- načina na koji su se stjecala znanja,

- opredjeljenja samog nastavnika.

Da bi uspjeh u učenju bio veći, primjenom ovog sistema potrebno je učeniku pružiti određene instrukcije. Te upute mogu biti definirane na sljedeći način:

1. Sagledaj u čemu je problem, utvrditi sredstva, način i put rješavanja;

2. Ne žuri $\mathrm{s}$ rješavanjem problema! Zadatak treba prethodno pažljivo pročitati, da bi se shvatila njegova bit, postojeće veze i odnosi;

3. Koristi se prethodnim znanjem i iskustvima;

4. Ne idi uvijek tačno utvrđenim redoslijedom, primjenjuj različite načine i puteve;

5. Ne plaši se nikakvog problema;

6. Budi istrajan i uporan;

7. Ne zadržavaj se dugo na pojedinim pretpostavkama i rješenjima, brzo se usmjeri i preorijentiraj na druge načine rješavanja;

8. Pravi kratke pauze u rješavanju zadataka;

9. Sakupljaj cjelovite podatke;

10. Budi kritičan u radu;

11. Provjeri pouzdanost nastavnog izvora;

12. Budi otvoren za nove ideje i rješenja;

13. Sagledaj što je dato u zadatku, što se traži, uporedi krajnja stanja da bi se bolje sagledala bit zadatka i odredilo u čemu je problem;

14. Pažnju usmjeri krajnjem cilju;

15. Koristi se poznavanjem opštih principa u rješavanju problema;

\section{Organizacija časa problemskog učenja}

Problemski čas se razlikuje od časa čija nam je struktura poznata iz prakse tradicionalne nastave.Učeničku potrebu da traga, otkriva, uviđa, istražuje treba da prati obrazovno dobro kojim se 
pobuđuje i održava ova potreba. Ovu potrebu treba da prati adekvatna organizacija i izvedba nastavnog sata.

Postupak organiziranja problemske nastave omogućuje da proces učenja postaje suvremeni sistem nastave, a ne da ostaje kao posebna didaktička metoda. Postupak organiziranja problemske nastave ima svoje konačno utemeljenje u učenju kao aktu otkrića.

Organizacija i nastavni postupci se tako biraju i podešavaju da maksimalno podstiču, održavaju misaonu aktivnost učenika i doprinose razvoju njihovih mentalnih sposobnosti.

Metod organiziranja problemske nastave izraz je nastavnikove stalne kreativnosti, a ne puko kopiranje i uporno ponavljanje nekog dosjetljivog, na nekom satu uspješno pokazanog metodičkog rješenja.

Nastavnik pri organizaciji treba da vodi računa o sljedećem:

- da je pristup realizacije nastavnog sadržaja originalan, neuobičajen, nesvakidašnji,

- da uvidi i osmisli vezu izabranog pristupa s problemskom situacijom koju kani samostalno ili zajedno s učenicima proizvesti,

- da samo polazište u sebi sadrži ili implicira problem ili problemsku situaciju,

- da polazište ima potrebnu kognitivnu usmjerenost i emocionalno - voljnu primamljivost za učenika.

Organizacija časa problemske nastave kroz faze kroz koje će on proći zavisi od više činilaca:

- prirode gradiva,

- problemskih zadataka koje on nameće,

- prethodnih znanja učenika,

- njihovog iskustva u rješavanju problema.

Cilj problemske nastave je:

- razumijevanje postavljenog problema

- razvijanje sposobnosti artikulacije misaonog procesa

- razvijanje komunikacijskih sposobnosti. 


\section{Artikulacija časa problemske nastave}

U organizacijskom pogledu učenje putem rješavanja problema ima sljedeći tok:

\section{a) Postavljanje - definiranje problema (stvaranje problemske situacije)}

U uvodnom dijelu časa nastavnik postavlja problemski zadatak i na taj način se stvara atmosfera radoznalosti, mobilizira njihova pažnja, izaziva misaona napetost i učenici se motiviraju za rad. To je faza stvaranja problemske situacije. Zadatak postaje problem tek kada ga učenici požele riješiti. Učenici, znači, uočavaju problem koji pokreće njihovo stvaralačko mišljenje, razvija inicijativu, intelektualni nemir, emocionalnu napetost. Kod njih se javlja doživljaj, trenutna zbunjenost, tenzija. Problemska situacija postoji za učenika tek onda kada je on osvijesti i formulira kao pitanje na koje mora dati (do tada bar njemu nepoznat) odgovor.

Početna (inicijalna) aktivnost je na strani nastavnika (koji saopćava zadatak), a učenik postaje svjestan teškoće. Zato je bitno da se problemski zadatak formulira precizno i jasno.

Problemsko pitanje treba izoštriti kako se u iznalaženju rješenja ne bi lutalo. Problemsko pitanje mora okupirati učenike, jer tada oni neće biti u položaju da pasivno primaju gotovo rješenja problema, nego će morati aktivno misliti i na taj način samostalno iznalaziti rješenja.

Ova faza je veoma važna za dalji tok misaone aktivnosti. Problemski zadatak je utoliko kvalitetniji ukoliko zahtjeva više napora od onoga koji ga rješava.

Za učenike neće svaki zadatak predstavljati problem. Dok će za jednog učenika zadatak biti problem, za drugog taj isti zadatak ne mora biti problem.

Pri davanju problemskog zadatka treba imati u vidu značaj pravilnog odmjeravanja zahtjeva. Ti zahtjevi se kreću u sljedećim dimenzijama: 
1. Zahtjevi su znatno niži u odnosu na učeničke mogućnosti u ovom slučaju problemski zadatak ne podstiče misaonu sktivnost, ne diže učenika, ne obrazuje ga, umrtvljuje njegovu radoznalost, njegovu ambiciju, pasivizira ga i uspavljuje. Problemski zadatak ne smije biti lišen teškoća i napora. U tom slučaju učenici se jednostavno posluže prethodnim znanjima i mehanički pružaju traženi odgovor.

2. Zahtjevi su primjereni mogućnostima učenika - i ovdje će učenici bez većeg misaonog napora doći do rješenja, a to onda za njih i nije problem. Učenici nisu u dovoljnoj mjeri aktivni, budući da u rješavanju problema mogu da primjene izvjesne sheme dolaska do rješenja. Takav problem djeluje više negativno, jer ne zahtjeva od učenika ozbiljan misaoni napor, oduzima mu vrijeme i sputava njegov intelektualni razvoj. Nema intelektualnog razvoja učenika bez većeg misaonog napora.

3. Zahtjevi su daleko iznad mogućnosti učenika - ako zahtjevi u zadatku daleko premašuju iskustvo, znanje i mogućnosti učenika, ako su učeničke mogućnosti precijenjene, onda učenik neće moći doći do rješenja. Teškoća kojom se karakterišu problem i problemska situacija ne smije ostaviti utisak nerješivosti. Razumije se da ako je učenik na trećoj stepenici na primjer, a problemski zadatak zahtjeva da se popne na sedmu ili osmu stepenicu, onda je on nepedagoški i učenik je unaprijed osuđen na neuspjeh. Učenik tada gubi volju da traži put njegovog rješavanja i pribjegava traženju lakših puteva( kao što je prepisivanje ) što razvija loše navike.

4. Zahtjevi su nešto viši nego što su to učeničke mogućnosti u takvim slučajevima učenici zbog izvjesnih nepoznatih situacija nisu u stanju da primjene od ranije poznate sheme.Oni uočavaju veze i odnose, analiziraju situacije i traže nove, do tada nepoznate puteve dolaska do rješenja. Ako su zahtjevi nešto viši kod učenika će se javiti prepreka, problem i želja da se upusti u traganje za rješenjem, javit će se želja da se zadatak riješi. To znači da problemski zadaci moraju biti tako graduirani da se učenik uz ozbiljan napor penje od jednog do 
drugog, ali da to penjanje ne bude naglo prekinuto, naglo onemogućeno zbog toga što su zahtjevi daleko iznad mogućnosti učenika

\section{b) Rješavanje problema (problemskog zadatka)}

Glavni dio časa je rješavanje problema. Smatra se da rješavanje problema predstavlja niz složenih operacija. Mladen Vilotijević ističe:“ Rešavanje problema je stvaralačka aktivnost, kojom se u susretu sa posebnim zahtevima traži pronalaženje novih rešenja“. On u svom djelu navodi sljedeće etape u rješavanju problema: ${ }^{9}$

\section{-Upoznavanje problema}

Pojedinac upoznaje elemente problema, nastoji da pronikne $\mathrm{u}$ njihove međusobne veze $\mathrm{i}$ odnose.

\section{-Sužavanje - reformulacija problema}

$\mathrm{Na}$ osnovu analize datih podataka i onoga što je zadato, pojedinac uviđa što nedostaje, $\mathrm{u}$ čemu je praznina koju treba popuniti, on analizira ono što je dato vodeći računa o zadatome i tako donekle sužava i konkretizuje problem, lokalizuje teškoću i traži način rješavanja.

\section{-Postavaljanje hipoteze}

Analizom datog zadatka i sagledavanjem teškoće pojedinac postavlja hipotezu za rješenje problema.

\section{-Provjeravanje hipoteze}

Kad se hipoteza javi, pojedinac polazi od toga da je ona ispravna, jer je potpuno u skladu sa načinom traženja koji je izabrao, jer može da popuni prazninu u datim podacima.Hipoteza je rješenje čiji ispravnost treba provjeriti.

Vladimir Poljak u trećoj didaktičkoj postavci problemske nastave ističe da se problem kao dijalektičko jedinstvo suprotnosti

\footnotetext{
${ }^{9}$ Mladen Vilotijević, Didaktika,Naučna knjiga, Učiteljski fakultet, Beograd, 1999. god.
} 
rješava tako što se polazi od poznatog dijalektičkog pola i prelazi na nepoznati dijalektički pol.

M. Rosandić smatra da faze rješavanja problema idu ovim redom: U prvoj fazi učenik uočava problem, osjeća teškoću i nedoumice, svjesno upravlja svoju spoznajnu aktivnost. U drugoj fazi problem se brže određuje, razlaže na elemente, traži rješenje.

U trećoj fazi postavljaju se problemska pitanja, hipoteze alternative, navode činjenice, traga za odnosima, traga za složenim problemima. Četvrta faza je verifikacija. ${ }^{10}$

I. Dizdarević u djelu“ Stvaralaštvo i društveno ponašanje mladih“ ističe da je , školsko znanje jedan od bitnih uslova kreativnog rješavanja problema. Pored toga, jedan od uvjeta za kreativno rješavanje problema jesu stvaralačke sposobnosti učenika." “11

Rješavanje problema je najefikasnije sredstvo za razvoj stvaralačkog mišljenja. Na Ganjeovoj hijerarhijskoj ljestvici tipova učenja, rješavanje problema je na samom vrhu, kao najsloženiji tip. Ganje kaže da se problemi rješavaju međusobnim povezivanjem pravila. Američki psiholog Robert Ganje smatra da su „problemi vrhunski tip učenja u hijerarhiji koja se kreće od najjednostavnijeg uslovljavanja preko učenja pojmova i načela do samog rješavanja problema" što ukazuje na kontinuirano učenje.

Proces rješavanja problema Ganje je vidio kroz četiri faze:

1. ustanovljenje problema,

2. određivanje bitnih karakteristika problema,

3. traženje i oblikovanje hipoteza, $\mathrm{i}$

4. provjeravanje rješenja.

U psihološkom smislu rješavanje problema je najviši oblik ljudskog učenja. To je takva situacija učenja u kojoj dominira neka teškoća, spornost, praznina u misaonom toku koju treba popuniti i riješiti problem.

\footnotetext{
${ }^{10}$ M. Rosandić, Metodika književnog odgoja i obrazovanja, Zagreb 1986. god.

${ }^{11}$ Stvaralaštvo i društveno ponašanje mladih, Sarajevo, 1980. god.
} 
Kreč i Kračfild opisali su proces rješavanja problema. U jednoj rečenici kazano je sljedeće: „Teškoća i složenost, sposobnost mislioca, njegove radne navike, zalihe starog znanja, motivacija, ličnost je.." onaj niz događaja koje sve nazivamo jednim imenom - procesom stvaralačkog rješavanja problema. ${ }^{12}$

$\mathrm{Za} \mathrm{B}$. Stevanovića rješavanje problema je najviši oblik učenja koje karakteriše uviđanje odnosa između sredstava, načina i puteva, $\mathrm{s}$ jedne, i cilja odnosno rješenja, s druge strane, i snalaženja u novoj situaciji učenja. ${ }^{13}$

\section{c) Zaključci (situacija cilja)}

Kad svi završe s radom, učitelj zahtjeva od učenika njihova rješenja. Učitelj treba znati kako su učenici riješili zadatak: uspješno, djelomično, pogrešno, nikako. Dakle, učitelj treba imati povratnu informaciju o tome koko su učenici riješili zadatak. Dakle, nije dovoljno da se povratna veza ostvaruje samo po kriterijumu tačnosti učenikovog odgovora. Odgovor na problemski zadatak je zapravo verifikacija postavljenih hipoteza, odnosno mogućih rješenja učenika. Verifikacijom hipoteze problem se rješava.

\section{d) Praktična primjena stečenih znanja u novim situacijama}

Znanja koja su učenici stekli moraju biti stavljena u funkciju. To se postiže na taj način što se učenicima daju zadaci koji su slični zadatku - uzoru, a pri tom se vodi računa da svaki zadatak bude za nijansu teži od prethodnog. $\mathrm{Na}$ taj način se dobiva povratna informacija o učeničkim postignućima.

\section{e) Domaća zadaća}

Davanje problema za domaći rad također ne smije biti rutinski dio posla. Zadaci se moraju pripremiti unaprijed. Učenicima se treba reći na šta trebaju obratiti posebnu pažnju. Dobri domaći zadaci i kontrola će mnogo pomoći učenicima da se znanja utvrde.

${ }^{12}$ D. Kreč, R. Kračfild, Elementi psihologije, Beograd, 1978. god.

${ }^{13}$ B. Stevanović, Pšedagoška psihologija, VII izdanje, Beograd, 1968. god. 


\section{Uloga nastavnika u problemskoj nastavi}

Uloga nastavnika u problemskoj nastavi se ogleda u sljedećem:

- da savjetima pomaže učenicima u izboru i radu

- da fokusira pažnju učenika na ono što je važno

- da kontrolira rad učenika

- da upozorava na pravilnu artikulaciju

- da vodi dijalog o izvršenom radu i rješavanju problemskog zadatka

Funkcija nastavnika usmjerena je u smislu organizatora, motivatora, programera. On naučno prilazi i organizira nastavu, realizira odgojno - obrazovne zadatke i nastavni sadržaj. Nastavnik težište svoje aktivnosti stavlja na osposobljavanje učenika za aktivno prihvatanje i korištenje informacija. pitanja:

U problemskoj nastavi nastavnik rješava nekoliko relevantnih

- vrši planiranje i selekciju nastavnog sadržaja za primjenu problemske nastave,

- odabire elemente za stvaranje problemske situacije,

- predviđa vlastitu djelatnost, ali i moguće odgovore učenike,

- rukovodi, promatra i aktivira intelelektualne, voljne i emocionalne karakteristike učenika, vrši izbor metoda, oblika i sredstava nastavnog rada,

- vrši izbor problema prema dobi učenika gdje provjerava $\mathrm{i}$ njihove optimalne mogućnosti,

- priprema pisani odgovor didaktičkim metodama,

- formulira stvarne ( a ne izmišljene) probleme,

- utvrđuje sistem motivacije postignuća za učenika itd.

\section{Uloga učenika}

Uloga učenika u problemskoj nastavi prvenstveno je stavljena u subjektivnu, istraživačku i aktivnu poziciju. Učenik je istraživač $i$ kreator.

Zadaci učenika su sljedeći: 
- razmišljati o problemu

- riješiti problem

- zapisati rješenje

- generalizovati

\section{Vrednovanje časa problemske nastave}

Čas problemske nastave kao i svaki drugi način rada treba da vrednuje sam nastavnik. On je prije svega dužan da nastavni rad tako organizira da na vrijeme dobije povratnu informaciju, ne samo da li su učenici riješili problem, već i da li su ga riješili na optimalan način.

Veliki značaj ima provjera rezultata u praksi.

Ako je povratna informacija o samom toku časa i o njegovom krajnjem ishodu nepovoljna, on sebi mora postaviti nekoliko pitanja:

- da li su problemski zadaci dobri, da li je te zadatke dovoljno funkcionalno i metodski pravilno koristio,

- da li je na početku časa stvorio dobru problemsku situaciju, da li je u toj fazi maksimalno motivirao učenike na misaonu aktivnost,

- da li je u toku časa dovoljno insistirao da učenici samostalno zaključuju

- da li je sam“ previše rukovodio“ časom i potisnuo učenike i njihovu misaonu aktivnost.

U toj ,samoanalizi“ on mora da nađe odgovore, utvrditi slabosti da bi ih u svom budućem radu mogao otkloniti. U suprotnom, ukoliko su se tokom časa javile neke situacije i pozitivna reagovanja učenika, učitelj će nastojati voditi računa o njima i u budućnosti.

\section{Metode problemske nastave}

U problemskoj nastavi najčešće se susrećemo sa sljedećim metodskim postupcima:

1. Problemsko čitanje je usmjereno samostalno čitanje $u$ sebi.Učenik vrši selekciju činjenica ", dekodira“ tekst, pronalazi relevantne i uzročno - posljedične činjenice. 
2. Problemsko izlaganje uključuje u sebe problemska pitanja i zadatke koji podraszumijevaju istraživački rad. To je zajednički rad nastavnika i učenika. U pitanju je aktivna obrada novog nastavnog gradiva.

3. Heuristički razgovor- centralno mjesto zauzima nastavnikovo pitanje koje pokreće učenika u otkrivanju novog. Ovdje je važan karakter otkrivanja. Pitanja donose nove spoznaje. Pitanja sadrže dio poruke koju odgovor upotpunjuje. Pitanja su nedorečena, a odgovori neizvjesni. Tehnika heurističkog razgovora tj. izbora pitanja zavisi od prirode nastavnog sadržaja, ciljeva i zadataka koje treba ostvariti.

Heuristički razgovor podrazumijeva najčešće sljedeća pitanja:

- problemska pitanja

- alternativna pitanja

- orijentaciona pitanja (usmjeravajuća pitanja)

- perspektivna pitanja (ona koja sigurnije vode k cilju)

- uopćena pitanja (zahtijevaju širu razradu i obrazloženje).

4. Istraživačka metoda primjenjuje se u procesu stjecanja novih znanja tj. na satovima obrade novog gradiva. Učenik samostalno prolazi kroz sve faze prema potrebi) koje su karakteristične za problemsko učenje. On samostalno istražuje i usvaja nastavni sadržaj.

5. Metoda problemsko - stvaralačkih zadataka riječ je o takvom tipu zadataka u koje su uključeni elementi problemske nastave. Ponekad će nastavnik ponuditi niz rješenja ( alternativa ), a učenik će samostalno vršiti selekciju.

\section{Metodičko - organizacijski oblici rada u problemskoj nastavi}

Od socioloških oblika rada u problemskoj nastavi zastupljeni su svi poznati oblici:

- individualni oblik rada

- rad u paru ( tandem )

- grupni oblik rada

- kolektivni (frontalni) oblik rada 


\section{Didaktička uputstva za uspješno rješavanje problema}

R. Kvaščev je dao upute koje se odnose na metodološki pristup u rješavanju problema.

Da biste uspješnije riješili probleme bilo koje vrste, morate pokušati da uradite sljedeće:

- Razgraničite prvo ono što je u zadatku dato, od onog što je zadato.

- Sada, kad ste otkrili jednu bitnu vezu između onog što je dato i zadato u zadatku, u kojem smjeru vas ta veza upućuje da istražite nove odnose između onog što je dato i zadato $u$ zadatku. Prvo pođite od najbližeg odnosa na koji ta veza upućuje, pa zatim tragajte za drugim udaljenijim odnosima na koje će vas usmjeriti otkrivena druga, zatim treća veza itd.

- Aktivirajte svoje staro znanje i pokušajte da ga primijenite na nov način u rješavanju date problemske situacije, tj. staro znanje povežite sa bitnim aspektima problemske situacije i, ako je potrebno, transformišite ga.

- Povežite sve otkrivene veze između onog što je dato i zadato u zadatku i pokušajte da ih uopćite tako da vam to omogućuje da usaglasite način rješavanja problema.

- U saglasnosti sa otkrivenim bitnim relacijama između onog što je dato i zadato u zadatku i njihovim uopćavanjem, razvijte najbolju metodologiju za rješavanje problema. ${ }^{14}$

Kračfild je razvio strategiju uspješnog rješavanja problema. Ova strategija sastoji se od:

- formuliranja i razrješavanja suštine problema;

- razvijanja plana rješavanja problema;

- povećavanja broja različitih ideja koje su neobične i rijetke;

- sistematiziranja otkrivenih ideja;

- uzdržavanja od brzog izvođenja zaključaka o tačnosti ideja i vrijednosti činjenica;

${ }^{14}$ Mujo Slatina, Nastavni metod - prrilog pedagoškoj moći suđenja, Filozofski fakultet Univerziteta u Sarajevu, 1998. god. 
- istraživanja novih činjenica $\mathrm{s}$ ciljem potrebe vrednovanja hipoteza;

- primjene najbitnijih činjenica;

- pokušaja da se problemi sagledavaju na nove i različite načine. $^{15}$

\section{Umjesto zaključka, apel nastavnicima:}

Mudrost redovito raste u omjeru čovjekove svijesti o vlastitom neznanju. Zato učenje treba upriličiti da cijeli svijet koristite kao učionicu, kombinirajte najbolje od novoga s najboljim od staroga. Što god možete učiniti, ili sanjate da možete, započnite. Odvažnost posjeduje genij, moć $i$ čaroliju zato, počnite odmah, isprobajte nešto od ovoga što smo vam ponudili.

\section{Literatura}

1. Bakovljev Milan: Didaktika, Naučna knjiga, V. izdanje, Beograd 1998. god.

2. Ćatić, Refik: Osnovi didaktike, Pedagoški fakultet, Zenica, 1998. god.

3. Dizdarević, I.: Stvaralaštvo i društveno ponašanje mladih, Sarajevo, 1980. god.

4. G., Olport: Sklop i razvoj ličnosti, Knjiga I, Beograd, 1985. god.

5. Kreč D., i Kračfild R.: Elementi psihologije, Beograd, 1978. god.

6. Jelavić, Filip: Didaktika, Naklada Slap, 1998. god.

7. Muminović, Hašim, : Mogućnosti efikasnijeg učenja u nastavi, DES, Sarajevo, 2001. god.

8. Poljak, Vladimir: Didaktika, Školska knjiga, Beograd, 1974. god.

9. Rosandić, Dragutin: Metodika književnog odgoja i obrazovanja, Zagreb, 1986. god.

10. Rot, Nikola: Opća psihologija, VII izdanje, 1966. god.

15 Mujo Slatina, Nastavni metod - prrilog pedagoškoj moći suđenja, Filozofski fakultet Univerziteta u Sarajevu, 1998. god. 
11. Slatina, Mujo: Nastavni metod, - Prlikog pedagoškoj moći suđenja, Filozofski fakultet Univrziteta u Sarajevu, 1998. god.

12. Stevanović, B.: Pedagoška psihologija, VII izdanje, Beograd, 1968. god.

13. Stevanović, Marko: Didaktika, Tuzla, 1998. god.

14. Vilotijević, Mladen: Didaktika I, Naučna knjiga, Učiteljski fakultet, Beograd, 1999. god.

15. Pedagoška enciklopedija II, Beograd, 1989. god.

16. Đubran, Halil: Prorok, Školska knjiga, Beograd, 1984. god. 
PROF.DR. REFIK ĆATIĆ, P.H.D.

\section{CHARACTERISTICS OF THE PROBLEM ORIENTED EDUCATION}

\section{SUMMARY}

Modern pedagogical conceptions are based on a pupil oriented education. Unlike traditional education, in modern educational systems teacher is becoming more and more a mediator between educational contents and pupils. He encourages pupils to explore and to discover, and by doing so, to gain knowledge from first hand.

„The one who wishes to teach us the truth,

Should not tell us, but use simple gesture,

Gesture which creates an ideal path in the air,

On which we sore until we confront new truth.“

H.Džubran, "The Prophet"

Problem oriented education is a concept which is based on the child's need to explore the enviroment that surrounds it.

This is why this study sublimates basic theoretical postulates of such educational strategies. 
أ. د. د. دفيق تشاتيتش

\section{خصائص الدراسة المشكِلِةِ}

خلاصة البحث

المفاهيم التربوية المعاصرة تقوم على الدراسة الموجّهة للتلميذ. لقد أصبح دور المدرّس في النظم

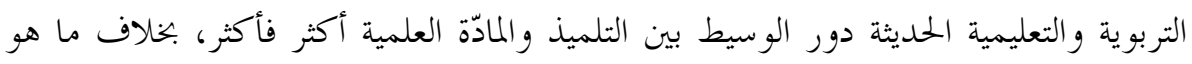

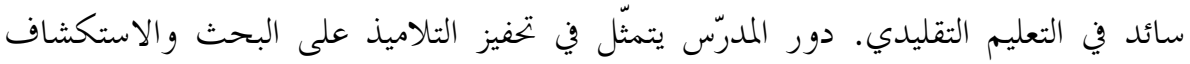

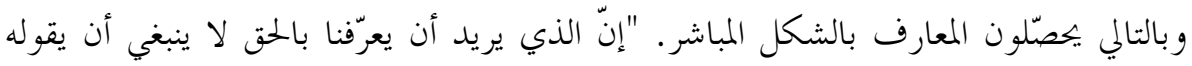

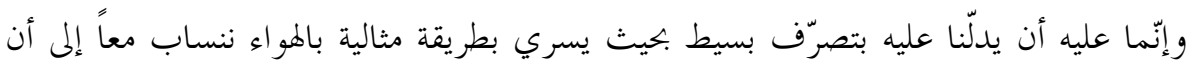
نصل بين يدي الحق الجديد" (جيران خليل جبران في كتابه "النبي").

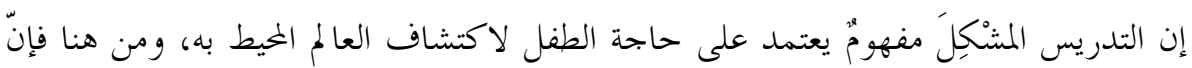
هذا البحث إعلاء لقضية أساسية مفترضة لتلك الاستر اتيجيات التربوية التعليمية. 